\title{
Compensatory Enhancement of Intrinsic Spiking upon NKCC1 Disruption in Neonatal Hippocampus
}

\author{
Sampsa T. Sipilä, ${ }^{3}$ Kristiina Huttu, ${ }^{1}$ Junko Yamada, ${ }^{1}$ Ramil Afzalov, ${ }^{1}$ Juha Voipio, ${ }^{1}$ Peter Blaesse, ${ }^{1}$ and Kai Kaila ${ }^{1,2}$ \\ ${ }^{1}$ Department of Biological and Environmental Sciences and ${ }^{2}$ Neuroscience Center, University of Helsinki, FI-00014 Helsinki, Finland, and ${ }^{3}$ Department of \\ Clinical Neurophysiology, Oulu University Hospital, FI-90230 Oulu, Finland
}

Depolarizing and excitatory GABA actions are thought to be important in cortical development. We show here that GABA has no excitatory action on $\mathrm{CA} 3$ pyramidal neurons in hippocampal slices from neonatal $\mathrm{NKCC1^{-/ }}$ mice that lack the $\mathrm{Na}-\mathrm{K}-2 \mathrm{Cl}$ cotransporter isoform 1. Strikingly, $N K C C 1^{-1-}$ slices generated endogenous network events similar to giant depolarizing potentials (GDPs), but, unlike in wild-type slices, the GDPs were not facilitated by the GABA agonist isoguvacine or blocked by the NKCC1 inhibitor bumetanide. The developmental upregulation of the $\mathrm{K}-\mathrm{Cl}$ cotransporter 2 (KCC2) was unperturbed, whereas the pharmacologically isolated glutamatergic network activity and the intrinsic excitability of CA3 pyramidal neurons were enhanced in the NKCC1 ${ }^{-1-}$ hippocampus. Hence, developmental expression of KCC2, unsilencing of AMPA-type synapses, and early network events can take place in the absence of excitatory GABAergic signaling in the neonatal hippocampus. Furthermore, we show that genetic as well as pharmacologically induced loss of NKCC1-dependent excitatory actions of GABA results in a dramatic compensatory increase in the intrinsic excitability of glutamatergic neurons, pointing to powerful homeostatic regulation of neuronal activity in the developing hippocampal circuitry.

\section{Introduction}

Depolarizing GABA actions have been ascribed a key role in the development of cortical neurons and networks. In the rodent hippocampus, the maturation of inhibitory and excitatory postsynaptic transmission takes place mainly during the first 2 weeks after birth (for review, see Ben-Ari et al., 2007; Blaesse et al., 2009; Wang and Kriegstein, 2009).

A characteristic feature of the immature hippocampus is the occurrence of spontaneous network events that have been termed giant depolarizing potentials (GDPs) (Ben-Ari et al., 1989). Spiking of the CA3 pyramidal cells plays a key role in GDP generation, and it has been attributed to a synchronous, depolarizing GABAergic input from the interneuronal network acting in a synergistic manner with NMDA receptors. Furthermore, this synergistic action is implicated in the functional activation of "AMPA-silent" synapses in immature neurons (Ben-Ari et al., 1997). Depolarizing GABAergic transmission has also been suggested to play an obligatory role in the developmental negative shift in the reversal potential of $\mathrm{GABA}_{\mathrm{A}}$-mediated responses $\left(E_{\mathrm{GABA}}\right)$ (Ganguly et al., 2001) (but see Ludwig et al., 2003; Titz et al., 2003).

In immature cortical neurons, two chloride transporters exert a major influence on $E_{\mathrm{GABA}}$. The $\mathrm{Na}-\mathrm{K}-2 \mathrm{Cl}$ cotransporter 1

Received Jan. 27, 2009; revised April 5, 2009; accepted April 23, 2009

This study was supported by the Academy of Finland, the Sigrid Juselius Foundation, European Integrated Project "EPICURE" Grant EFP6-037315 (K.K.), the Finnish Medical Foundation (S.T.S.), the Paulo Foundation (S.T.S.), and a fellowship from the German Academic Exchange Service (P.B.). K.K. is a member of the Finnish Centre of Excellence $(\mathrm{COE})$ in Molecular and Integrative Neuroscience Research and the Nordic CoE WIRED.

Correspondence should be addressed to Prof. Kai Kaila, Department of Biological and Environmental Sciences, University of Helsinki, FI-00014 Helsinki, Finland. E-mail: kai.kaila@helsinki.fi.

DOI:10.1523/JNEUROSCI.0443-09.2009

Copyright $\odot 2009$ Society for Neuroscience $\quad$ 0270-6474/09/296982-07\$15.00/0
(NKCC1) takes up $\mathrm{Cl}^{-}$and is responsible for the depolarizing GABA actions (Yamada et al., 2004; Sipilä et al., 2006b; Achilles et al., 2007). During neuronal maturation, $\mathrm{K}-\mathrm{Cl}$ cotransporter 2 (KCC2) is upregulated, rendering $E_{\mathrm{GABA}}$ hyperpolarizing (Rivera et al., 1999).

Here we demonstrate that CA3 pyramidal neurons from neonatal mice with a disruption in the NKCC1 gene Slc12a2 $\left(\mathrm{NKCC1}^{-/-}\right)$do not have excitatory $\mathrm{GABA}_{\mathrm{A}}$ receptor-mediated responses. Strikingly, however, this was found to result in unperturbed KCC2 expression and in enhanced AMPA receptordependent network activity. In addition, a dramatic increase in the intrinsic excitability of CA3 pyramidal cells was seen in the $\mathrm{NKCC1}^{-/-}$neurons and also in wild-type (WT) neurons after prolonged $(>2 \mathrm{~h})$ pharmacological block of the transporter, which indicates that compensatory mechanisms promoting homeostatic plasticity are activated in response to the absence of depolarizing GABA actions.

\section{Materials and Methods}

The experimental procedures were approved by the local Ethics Committee for Animal Research at the University of Helsinki.

The mouse strain with a disruption of the gene Slc12a2 coding for the NKCC1 protein (Flagella et al., 1999) was obtained from The Jackson Laboratory.

Electrophysiological recordings. Coronal and horizontal brain slices $(300-400 \mu \mathrm{m})$ from postnatal day 0 (P0) to $\mathrm{P} 7$ pups were prepared as described previously (Sipilä et al., 2005). Individual slices were transferred into a submersion-type recording chamber perfused with standard solution $\left(32^{\circ} \mathrm{C}\right)$. The standard solution contained $124 \mathrm{~mm} \mathrm{NaCl}, 4.0$ mм KCl, $2.0 \mathrm{~mm} \mathrm{CaCl}$, $25 \mathrm{~mm} \mathrm{NaHCO}, 1.1 \mathrm{~mm} \mathrm{NaH}_{2} \mathrm{PO}_{4}, 1.3 \mathrm{~mm}$ $\mathrm{MgSO}_{4}$ and $10 \mathrm{~mm}$ D-glucose, equilibrated with $5 \% \mathrm{CO}_{2}$ plus $95 \% \mathrm{O}_{2}$, $\mathrm{pH} 7.4$ at $32^{\circ} \mathrm{C}$.

The CA3 pyramidal neurons were visually identified using infrared video microscopy. An Axopatch 200A amplifier was used for whole-cell 
recordings. Patch pipettes (5-8 $\mathrm{M} \Omega$ ) were filled with either of the following (in mM): $140 \mathrm{Cs}$-methanesulfonate, $2 \mathrm{MgCl}_{2}$, and $10 \mathrm{HEPES}, \mathrm{pH}$ 7.2 with $\mathrm{CsOH}$; or $95 \mathrm{~K}$-gluconate, $40 \mathrm{KCl}, 5 \mathrm{NaCl}, 2 \mathrm{MgCl}_{2}$, and 10 HEPES, pH 7.2 with $\mathrm{KOH}$. The recorded voltage was corrected with a calculated -13 or $-11 \mathrm{mV}$ liquid junction potential for the two filling solutions, respectively. Miniature EPSCs (mEPSCs) were recorded with the $\mathrm{K}^{+}$-gluconate based filling solution at a holding potential of $-70 \mathrm{mV}$ in the presence of $100 \mu \mathrm{M}$ picrotoxin and $1 \mu \mathrm{M}$ tetrodotoxin.

An EPC10 patch-clamp amplifier (HEKA) was used for gramicidin perforated-patch recordings. Patch pipettes (3-4 M $\Omega$ ) were filled with $150 \mathrm{~mm} \mathrm{KCl}$ and $10 \mathrm{~mm}$ HEPES, pH 7.2 with $\mathrm{KOH}$. Action potentials were blocked with $0.5-1 \mu \mathrm{M}$ TTX (Tocris Cookson). Recorded voltage was corrected for a calculated $-3.6 \mathrm{mV}$ liquid junction potential. Only cells with resting membrane potential below $-50 \mathrm{mV}$ were accepted for analyses. GABA was photolysed from a $\alpha$-carboxy-2-nitrobenzyl-caged GABA compound (Invitrogen) using local uncaging at the soma as described previously (Khirug et al., 2005).

Extracellular field potential (fp) recordings were performed with $\mathrm{NaCl}$-filled (150 mM) glass capillary electrodes (tip diameter, 5-15 $\mu \mathrm{m}$ ) placed in the stratum pyramidale of area CA3.

2,3-Dioxo-6-nitro-1,2,3,4-tetrahydrobenzo[f] quinoxaline-7-sulfonoamide (NBQX), D,L-AP-5, bicuculline methobromide, and isoguvacine hydrochloride were from Tocris Cookson. Picrotoxin, and bumetanide [3-(aminosulfonyl)-5 (butylamino)-4-phenoxybenzoic acid] were from Sigma. Extracellular $\mathrm{K}^{+}$was elevated by adding $\mathrm{KCl}$ to the standard solution. GYKI53655 [1-(4-aminophenyl)-3-methylcarbamyl-4-methyl-7,8-methylenedioxy-3,4-dihydro-5H-2,3-benzodiazepine] was a kind gift from Dr. Dietmar Schmitz (Neuroscience Research Center, Charité, Berlin, Germany).

Data were low-pass filtered at $1.6 \mathrm{kHz}$ and digitized at $5 \mathrm{kHz}$ for analyses using the Clampfit (Molecular Devices) and Strathclyde Electrophysiology WinWCP and WinEDR (John Dempster, University of Strathclyde, Glasgow, UK) programs and software programmed under Labview (National Instruments). In field recordings, the analysis of extracellular events was performed as described previously (Sipilä et al., 2005). Network events in fp recordings were visually detected with an amplitude threshold of $\sim 25 \mu \mathrm{V}$. Bandpass filtering was used to highlight population events in the illustrations. Miniature EPSCs were detected using WinEDR, and events $>3.5 \mathrm{pA}$ were accepted for analyses.

Calcium imaging. We found that making reliable cell-attached recordings from CA3 pyramidal neurons exposed for a prolonged time $(>2 \mathrm{~h})$ to bumetanide was difficult and often resulted in what was obviously damage-induced spiking, perhaps because this drug interferes with cellular volume regulation (Blaesse et al., 2009). Hence, to find out whether a compensatory mechanism similar to that seen at the level of endogenous spiking in the $\mathrm{NKCC1}^{-1-}$ neurons takes place in bumetanideexposed neurons, we monitored spiking activity by using $\mathrm{Ca}^{2+}$ imaging. Horizontal slices (500-600 $\mu \mathrm{m}, \mathrm{P} 5-\mathrm{P} 7)$ were incubated in the standard solution at $32^{\circ} \mathrm{C}$ for $90 \mathrm{~min}$ and thereafter loaded with the $\mathrm{Ca}^{2+}$-sensitive dye Fluo-4 AM ( $5 \mu \mathrm{M}$; Invitrogen) for $60 \mathrm{~min}$. After this, GABAergic and glutamatergic transmission were blocked by $100 \mu \mathrm{M}$ picrotoxin, $40 \mu \mathrm{M}$ $\mathrm{D}, \mathrm{L}-\mathrm{AP}-5$, and $20 \mu \mathrm{M} \mathrm{CNQX}$ during the $\mathrm{Ca}^{2+}$-imaging experiments. To record spontaneous spike-associated $\mathrm{Ca}^{2+}$ events in CA3 pyramidal cell somata, Fluo- 4 was excited at $810 \mathrm{~nm}$ in a multiphoton mode using a Mai Tai titanium:sapphire laser (Spectra Physics), and the emitted light was filtered at $500-560 \mathrm{~nm}$. The confocal section thickness was $\sim 5 \mu \mathrm{m}$ at a depth of $50 \mu \mathrm{m}$ in the slice. Images were acquired with a $40 \times$ waterimmersion objective using a modified confocal microscope (Radiance 2000; Bio-Rad) at a $3 \mathrm{~Hz}$ rate. Changes in $\left[\mathrm{Ca}^{2+}\right]_{\mathrm{i}}$ were quantified as $I=$ $\left(F-F_{\mathrm{b}}\right) / F_{\mathrm{b}}$, where $F_{\mathrm{b}}$ is the basal and $F$ the instantaneous level of Fluo- 4 fluorescence after background subtraction. Unit activity was recorded in slices exposed for $>2.5 \mathrm{~h}$ to bumetanide and in control slices kept in standard solution for an equal period of time. The criterion threshold for a unit event was set at a peak amplitude that was five times higher than the level of root-mean-square background noise, and the data were quantified in an experiment-blind manner. The $\mathrm{Ca}^{2+}$ transients were fully blocked in the presence of $1 \mu \mathrm{M}$ TTX, which indicates that they reflect neuronal spiking.

Immunoblot analysis. Proteins were separated from whole hippocampi of P3-P20 mice by SDS-PAGE on an 8\% gel. Gel loading was done in a buffer containing $80 \mathrm{~mm}$ Tris- $\mathrm{HCl}, 2 \%$ SDS, $10 \%$ glycerol, and $5.3 \%$ $\beta$-mercaptoethanol to solubilize KCC2. Electrophoretic separation lasted $1.5 \mathrm{~h}$. Proteins were electrophoretically transferred to polyvinylidene difluoride membranes (GE Healthcare) in transfer buffer containing $25 \mathrm{~mm}$ Tris, $192 \mathrm{~mm}$ glycine, and 10\% methanol, $\mathrm{pH}$ 8.3. Membranes were incubated in TBST/milk (20 mm Tris, $150 \mathrm{~mm} \mathrm{NaCl}, 0.1 \%$ Tween 20 , and $5 \%$ nonfat dry milk, $\mathrm{pH} 7.5$ ) with the respective antiserum overnight in the refrigerator. Rabbit anti-KCC2 (1:3000) (Ludwig et al., 2003) was used for KCC2 and rabbit anti-tubulin (1:20,000; Sigma) for the neuronal class III $\beta$-tubulin. After four washes in TBST, the secondary antibody (1:3000, donkey anti-rabbit IgG horseradish peroxidase conjugated; Dako) was applied for $4 \mathrm{~h}$ at room temperature in TBST/milk. After four washes in TBST, bound antibodies were detected using an enhanced chemiluminescence kit (Pierce) and an LAS-3000 documentation system (Fujifilm). The high concentration of $\beta$-mercaptoethanol in the gel-loading buffer ensured that KCC2 immunoreactivity (IR) was mainly present as a band with a molecular weight of $\sim 135 \mathrm{kDa}$ (Blaesse et al., 2006). Quantification of the volume of the KCC2-immunoreactive band on immunoblots was performed using NIH ImageJ (http://rsb. info.nih.gov/ij/). The KCC2-IR was first normalized to the tubulin-IR from the same sample and second to the normalized KCC2-IR of a P20 WT sample, which was present on all gels used for quantification.

Statistical analyses. Unless otherwise stated, data are presented as mean $\pm \mathrm{SEM}$, and quantitative comparisons were based on MannWhitney $U$ or Wilcoxon's signed rank tests. $p$ values $<0.05$ were considered statistically significant.

\section{Results}

\section{Developmental upregulation of KCC2 is unaffected in the} NKCC1 $1^{-/-}$hippocampus

We used laser photolysis of caged GABA in gramicidin perforated-patch voltage-clamp recordings for the measurement of $E_{\mathrm{GABA}}$ (Sipilä et al., 2006b). In agreement with previous findings that the specific NKCC1 inhibitor bumetanide fully blocks depolarizing GABAergic currents in neonatal pyramidal neurons (Sipilä et al., 2006b; Tyzio et al., 2006), $E_{\mathrm{GABA}}$ was much more negative (by $\sim 16 \mathrm{mV}$ ) in $N K C C 1^{-1-}$ versus WT P3-P4 CA3 pyramidal neurons $(-58.3 \pm 2.0 \mathrm{mV}, n=16 \mathrm{vs}-42.4 \pm 1.6 \mathrm{mV}$, $n=8$ in $\mathrm{NKCC1}^{-/-}$vs WT, respectively; $p=0.001$ ) (Fig. $1 A$ ). In the $N K C C 1^{-/-}$neurons, $E_{\mathrm{GABA}}$ was not significantly different from the value of $V_{\mathrm{m}}$ recorded at zero current, whereas the driving force $\left(E_{\mathrm{GABA}}-V_{\mathrm{m}}\right)$ was strongly depolarizing in WT neurons $\left(-1.2 \pm 1.3 \mathrm{vs} 16.6 \pm 1.7 \mathrm{mV}\right.$ in $N K C C 1^{-1-}$ vs WT, respectively).

Next, we asked whether the developmental expression of the $\mathrm{K}-\mathrm{Cl}$ cotransporter $\mathrm{KCC} 2$ is dependent on NKCC1-mediated depolarizing actions of GABA (see Introduction). Notably, a large increase in a single band in the range of $135 \mathrm{kDa}$, which is the expected molecular weight of the KCC2 monomer (Payne, 1997), was seen between P3/P4 and P20 in immunoblots with samples from both WT and $N \mathrm{KCC1}^{-1-}$ hippocampi $(p=$ 0.00009 and $p=0.00000004$ ) (Fig. $1 B$ ). There was no significant difference in the KCC2 protein levels between the genotypes.

\section{Spontaneous network events are present in $\mathrm{NKCC1}^{-/-}$ hippocampal slices}

When the WT neurons were held at $0 \mathrm{mV}$ using the low-chloride (4 mM) pipette solution, we observed bursts of GABAergic outward currents (Fig. 2A) associated with GDPs (Sipilä et al., 2006b). They occurred at a frequency of $0.004-0.02 \mathrm{~Hz}$, with a peak amplitude of $170 \pm 30 \mathrm{pA}$ (range, 70-290 pA) and a total duration of $1300 \pm 50 \mathrm{~ms}$ (range, 1200-1500 ms). Strikingly, spontaneous $\mathrm{GABA}_{\mathrm{A}}$ receptor-mediated bursts of outward currents similar to those above were also seen in the $\mathrm{NKCC1}^{-/-}$ neurons ( 11 of 12 individual cells in 7 of 7 slices from 3 of 3 
$\mathrm{NKCC1}^{-/-}$mice pups) (Fig. $2 \mathrm{~A}$ ) at a frequency of $0.002-0.04 \mathrm{~Hz}$, with a peak amplitude of $150 \pm 35 \mathrm{pA}$ (range, $30-350 \mathrm{pA}$ ) and a total duration of $1200 \pm 240 \mathrm{~ms}$ (range, 500-3000 ms).

In $\mathrm{fp}$ recordings, field GDPs (fGDPs) typically consisted of a slow negative deflection associated with spikes but frequently included both positive and negative slow components (Fig. $2 \mathrm{~B}$ ). In WT slices, fGDP frequency was $0.060 \pm 0.015$ $\mathrm{Hz}$, peak-to-peak amplitude was $84 \pm 19$ $\mu \mathrm{V}$, and duration was $390 \pm 42 \mathrm{~ms}(n=11$ slices, 463 fGDPs). In $N K C C 1^{-/-}$slices, the corresponding values were $0.029 \pm$ $0.007 \mathrm{~Hz}, 100 \pm 24 \mu \mathrm{V}$, and $230 \pm 29 \mathrm{~ms}$ ( $n=9$ slices, 193 fGDPs), respectively (Fig. $2 B$ ). The difference was statistically significant with respect to mean frequency $(p=0.044)$ and duration $(p=0.017)$ but not with respect to mean amplitude $(p=$ $0.52)$.

The parameters above represent grand average values. However, visual inspection of individual recordings suggested that the fGDPs (Fig. $2 B$, insets) and the intracellular GDP-associated GABAergic bursts (Fig. $2 A$, insets) show more variation in the $\mathrm{NKCC1}^{-/-}$than in the WT slices. In line with this, the coefficient of variation of the peak-to-peak amplitude and the duration of the fGDPs were larger in the $\mathrm{NKCC1}^{-/-}$versus WT slices $(0.5 \pm 0.05$ vs $0.28 \pm 0.03$ in $N K C C 1^{-/-}$vs WT, respectively, $p=0.0007$; and $0.34 \pm 0.044$ vs $0.17 \pm 0.015$ in $\mathrm{NKCC1}^{-/-}$vs WT, respectively, $\left.p=0.0016\right)$.

In additional agreement with the conclusion that GDPs are associated with a large GABAergic conductance in $\mathrm{NKCC1}^{-/-}$ slices, these events were seen as bursts of inward currents in voltage-clamp recordings at $-60 \mathrm{mV}$ using the $49 \mathrm{mM} \mathrm{Cl}^{-}$pipette solution. In simultaneous whole-cell and field-potential recordings, the intracellular GDPs coincided with fGDPs (Fig. 2C).

Intact neonatal $\mathrm{NKCC1}^{-/-} \mathrm{CA} 3$ pyramidal neurons fired one to seven spikes $(2.3 \pm 1.6$, mean \pm SD) during 31 of $48(65 \%)$ network events as seen in simultaneous field-potential and cellattached recordings ( $n=5$ neurons) (Fig. $2 C$ ), despite the large GDP-associated GABAergic conductance (Fig. 2A,C), which must have a shunting action (Figs. $1 A, 3 A$ ).

\section{Exogenous GABAergic enhancement of GDP frequency is absent in the $\mathrm{NKCC1} 1^{-/-}$mice}

GDP frequency is enhanced by a depolarization caused by $\mathrm{GABA}_{\mathrm{A}}$ receptor agonists (Khalilov et al., 1999) or by elevated extracellular $\mathrm{K}^{+}$(Sipilä et al., 2005). Isoguvacine (5 $\left.\mu \mathrm{M}\right)$ caused a profound, transient increase in fGDP frequency in P0-P1 WT mouse slices within $2 \min (670 \pm 150 \% ; p=0.02, t$ test; $n=7)$ (Fig. 3A). Isoguvacine did not increase fGDP frequency in $N K C C 1^{-1-}$ slices $(130 \pm 50 \% ; p=0.75, t$ test; $n=6)$ (Fig. $3 A$ ). Prolonged application led to complete suppression of fGDPs in both genotypes, which is expected because of the collapse of the $\mathrm{Cl}^{-}$gradient (WT) and of the shunting inhibitory action of GABA (Khalilov et al., 1999; Jean-Xavier et al., 2007). That a tonic depolarization promotes fGDPs in both WT and $\mathrm{NKCC1}^{-1-}$ slices was verified in experiments in which an elevation of extra- cellular $\mathrm{K}^{+}$increased their frequency (data not shown; $n=6$ and $n=4$, respectively) (cf. Sipilä et al., 2005).

\section{GDPs are blocked by bumetanide in WT but not in $\mathrm{NKCC1}^{-/-}$mice}

Bumetanide $(10 \mu \mathrm{M})$ completely blocked fGDPs within 2-7 min in six of six slices from WT mice (Dzhala et al., 2005; Sipilä et al., $2006 \mathrm{~b}$ ), but it had no detectable effect on fGDP frequency ( $90 \pm$ $15 \%$ vs control; $p=0.35 ; n=6$ ) in $N \mathrm{KCC}^{-/-}$slices (Fig. $3 B$ ). These results point to an enhancement of network excitability in $\mathrm{NKCC1}^{-1-}$ slices that compensates for the lack of GABAergic depolarization. Notably, an analogous compensatory effect was seen in experiments on WT slices (four of four slices) in which fGDPs reappeared within $1-3 \mathrm{~h}$ despite the continuous presence of bumetanide (Fig. 3C).

Functional AMPA transmission and increased excitability of pyramidal neurons in $\mathrm{NKCC1}^{-/-}$slices

In agreement with previous data from rat slices (Bolea et al., 1999; Lamsa et al., 2000), exposure of WT mouse slices to the AMPA/ kainate blocker NBQX $(10-50 \mu \mathrm{M})$ resulted in a near-complete inhibition of fGDP frequency to $9.2 \pm 3.4 \%$ (median, $6.5 \%$; range, $0-26 \%$ ) of control ( $n=9 ; p=0.00017$ ) (Fig. $4 A$ ). NBQX fully blocked fGDPs in four of four $\mathrm{NKCC1}^{-/-}$slices (Fig. $4 A$ ).

The $\mathrm{GABA}_{\mathrm{A}}$ antagonist picrotoxin $(100 \mu \mathrm{M})$ either reduced (13 of 20 recordings) or increased fGDP frequency (7 of 20). However, unlike in the rat, in which $\mathrm{GABA}_{\mathrm{A}}$ antagonists reduce average GDP occurrence (Sipilä et al., 2005; Ben-Ari et al., 2007), the grand average from all experiments obtained within 5-10 min after the onset of picrotoxin application was unchanged in WT slices $(0.019 \pm 0.006 \mathrm{~Hz}$ in picrotoxin vs $0.026 \pm 0.006 \mathrm{~Hz}$ in 
A
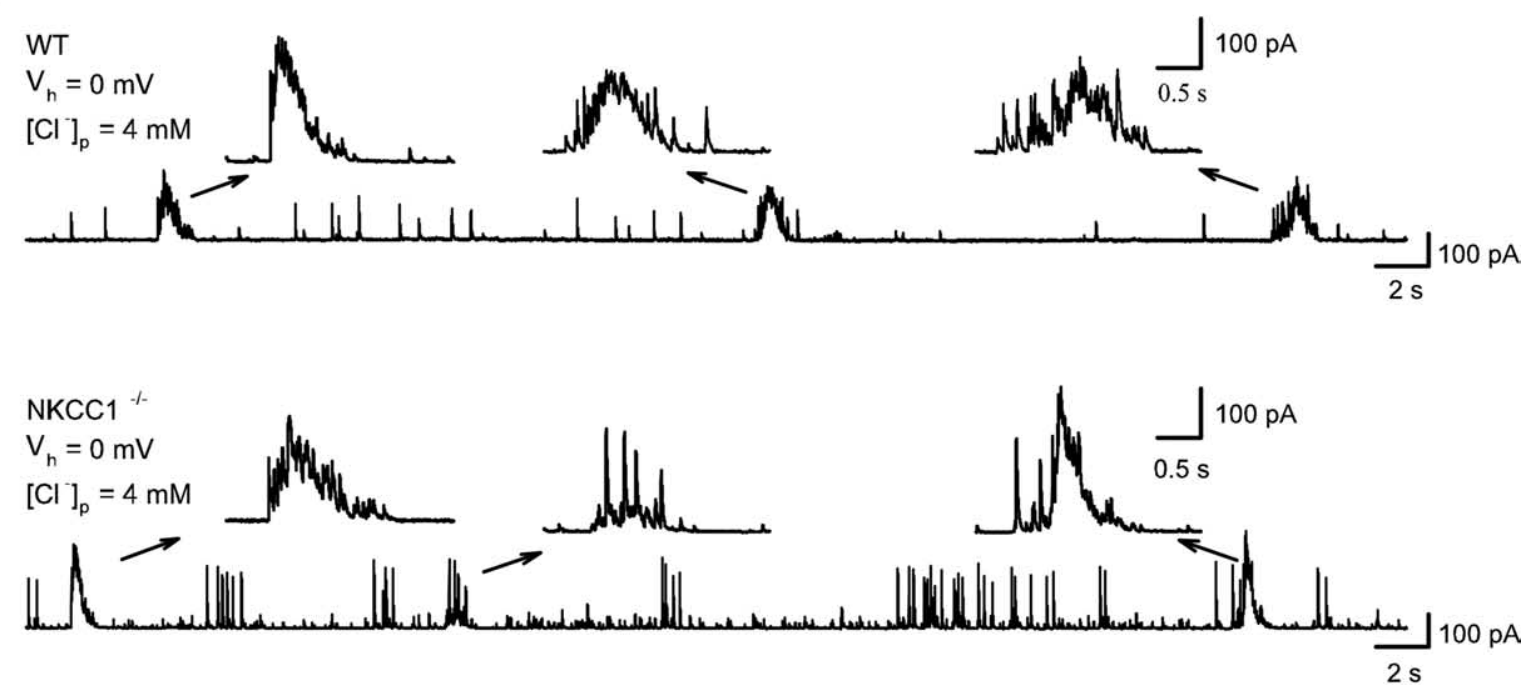

B

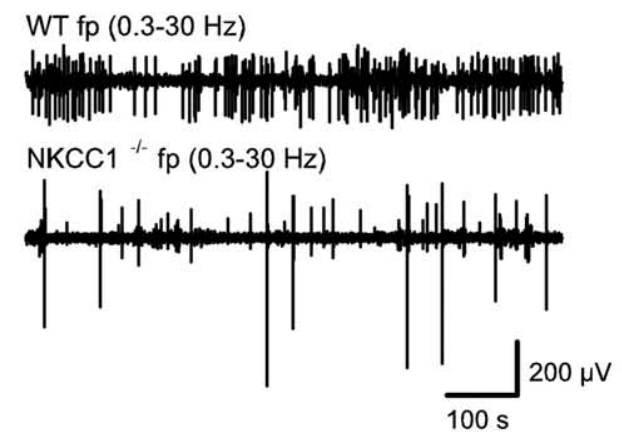

C

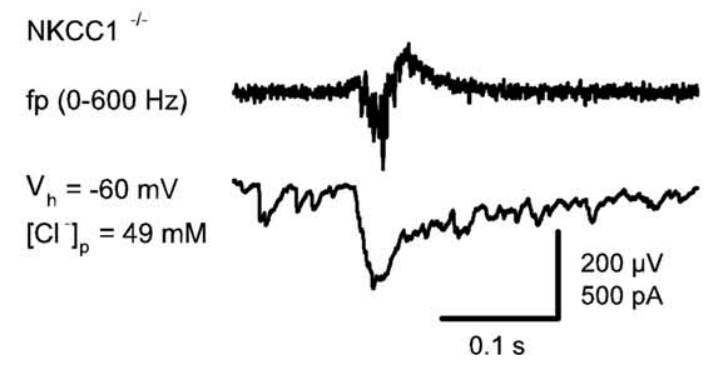

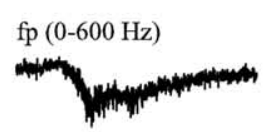
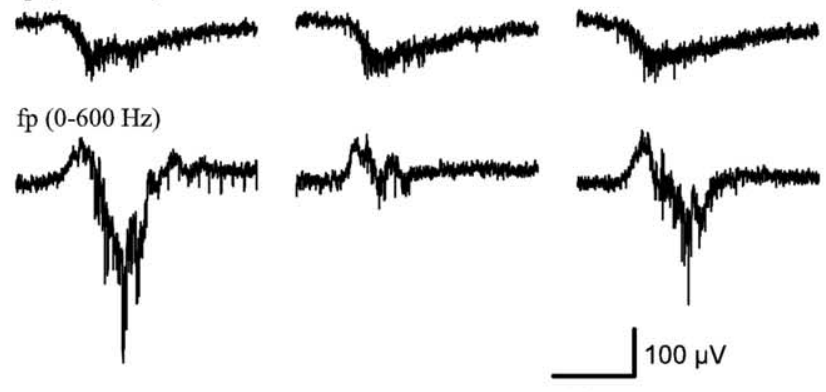

$100 \mu \mathrm{V}$

$0.2 \mathrm{~s}$

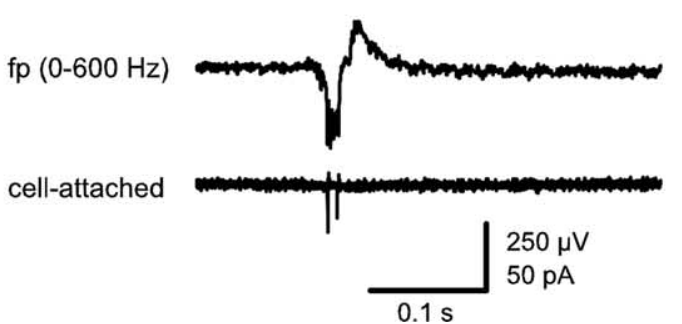

Figure 2. Network events similar to GDPs are generated by neonatal $\mathrm{NKCC}^{-/-}$hippocampal slices. $A$, Whole-cell voltage-clamp recordings with the low-chloride (4 mM) pipette filling solution at $0 \mathrm{mV}$ showing spontaneous unitary postsynaptic currents and GDPs seen as bursts of GABAergic currents (insets) in WT (top trace and insets) and NKCC $1^{-/-}$(bottom trace and insets) hippocampal slices. $\boldsymbol{B}$, fp recordings demonstrating that the variability of fGDP amplitude and duration is higher in $\mathrm{NKCC}^{-1-}$ (bottom traces) than in WT (top traces) slices. Continuous fp recordings and sample fGDPs are shown on the left and right, respectively. C, Left, Simultaneous fp recording (top trace) and whole-cell recording with the high-chloride ( $49 \mathrm{~mm}$ ) pipette filling solution at $-60 \mathrm{mV}$ (bottom trace) showing a GDP in an $\mathrm{NKCC}^{-/-}$slice. Right, Simultaneous fp (top trace) and cell-attached (bottom trace) recordings showing a GDP from an NKCC1 ${ }^{-/-}$slice.

control; $p=0.39, t$ test; $n=20$ ) (Fig. $4 B$ ). In P0-P1 NKCC1 ${ }^{-1-}$ slices, picrotoxin increased network event frequency from $0.016 \pm 0.005$ to $0.055 \pm 0.009 \mathrm{~Hz}(p=0.0003, t$ test; $n=29)$ (Fig. $4 B$ ), which was higher than in WT slices ( $p=0.005, t$ test). These results show that the excitability of the pyramidal cell network is enhanced in the $\mathrm{NKCC1}^{-/-}$versus the WT hippocampus in the absence of $\mathrm{GABA}_{\mathrm{A}}$ signaling. The events were fully blocked by the AMPA receptor-specific blocker GYKI53655 $(20 \mu \mathrm{M})$ in both genotypes $\left(n=4 \mathrm{WT} ; n=4 \mathrm{NKCC1}^{-1-}\right)$ (Fig. $\left.4 B\right)$, indi- cating that AMPA synapses are functional already at birth not only in the WT but also in the $\mathrm{NKCC1}^{-/-}$hippocampus.

The average frequency or amplitude of mEPSCs was not different between WT and $\mathrm{NKCC1}^{-/-} \mathrm{P} 5-\mathrm{P} 6 \mathrm{CA} 3$ pyramidal neurons (Fig. 4C) [frequency, $0.70 \pm 0.15$ vs $0.83 \pm 0.21 \mathrm{~Hz}, p=$ 0.63 , $t$ test; amplitude, $16.3 \pm 2.2$ vs $17.3 \pm 3.3 \mathrm{pA}, p=0.28$, $t$ test, in WT $(n=25)$ vs $\mathrm{NKCC1}^{-1-}(n=20)$, respectively]. The proportion of bigger events was slightly higher in the $\mathrm{NKCC1}^{-/-}$ $(3.1 \pm 1.2 \%$ of events $>70 \mathrm{pA})$ versus WT $(0.6 \pm 0.3 \%$ of $\mathrm{mEP}-$ 
SCs $>70 \mathrm{pA})$ neurons $(p=0.032 t$ test $)$ (Fig. 4C). The mEPSCs were blocked by 20 $\mu \mathrm{M}$ GYKI53655 (data not shown), which further confirms the presence of functional AMPA receptors in the $\mathrm{NKCC1}^{-/-}$ neurons. The input resistance was similar in the WT $(1.23 \pm 0.10 \mathrm{G} \Omega)$ and $N K C C 1^{-/-}(1.13 \pm 0.15 \mathrm{G} \Omega)$ neurons ( $p=0.58 t$ test).

We studied the intrinsic spiking propensity of the CA3 pyramidal neurons using cell-attached recordings in the absence of ionotropic glutamatergic and GABAergic signaling (in NBQX, AP-5, and picrotoxin). Intrinsic spiking frequency was dramatically (sixfold) higher in P6-P7 $\mathrm{NKCC1}^{-/-}$versus WT CA3 pyramidal neurons $(1.86 \pm 0.60 \mathrm{~Hz}, n=9$ and $0.32 \pm$ $0.11 \mathrm{~Hz}, n=11$, respectively; $p=0.01$ ) (Fig. 4D), which points to a major role for this effect in the compensatory mechanisms that enable GDP-like activity in the absence of depolarizing GABAergic transmission. In line with this result, the occurrence of spontaneous calcium transients (recorded in the presence of CNQX, AP-5, and picrotoxin) in CA3 pyramidal neurons was much higher (threefold) in WT slices incubated in $10 \mu \mathrm{M}$ bumetanide for $2-3 \mathrm{~h}$ than in control slices. In addition, the relative number of spontaneously active cells increased by a factor of 1.6 in the bumetanide-exposed slices (see supplemental data, available at www. jneurosci.org as supplemental material).

\section{Discussion}

Depolarizing $\mathrm{GABA}_{\mathrm{A}}$ actions based on $\mathrm{Cl}^{-}$uptake by NKCC1 promote GDPs in the neonatal rat hippocampus (Dzhala et al., 2005; Sipilä et al., 2006b). In agreement with this, GDP occurrence was increased by isoguvacine and blocked by bumetanide in WT mouse slices. An unexpected observation was that GDP-like spontaneous network events were present in the $\mathrm{NKCC1^{-1- }}$ slices. This indicates that compensatory mechanisms can substitute for the NKCC1-dependent facilitatory actions of depolarizing GABA in the generation of GDPs. Another intriguing finding was that GDPs reappeared during a prolonged application of bumetanide in WT slices, which points to the emergence of acute compensatory mechanisms in response to a drug-induced block of NKCC1 (cf. Chub and O'Donovan, 1998). This kind of an acute compensation is a factor that should be kept in mind in ongoing studies on bumetanide as a putative novel anticonvulsant in human neonates (Blaesse et al., 2009).

Isoguvacine did not promote the GDP-like events in $N K C C 1^{-1-}$ slices, which indicates that no other $\mathrm{Cl}^{-}$-uptake mechanism substitutes for NKCC1 in the knock-out (KO) neurons. Furthermore, KCC2 expression was similar, and not decreased, in $\mathrm{NKCC1}^{-/-}$versus WT hippocampi. Notably, this result shows that depolarizing postsynaptic $\mathrm{GABA}_{\mathrm{A}}$ responses are not critical for the developmental upregulation of KCC2 as pos- tulated by Ganguly et al. (2001). This is in agreement with more recent studies on primary cultures (Ludwig et al., 2003; Titz et al., 2003 ) and on a transgenic mouse line, in which vesicular GABA release was inhibited but KCC2 mRNA and protein expression levels were unaffected (Wojcik et al., 2006).

The frequency of network events seen in the absence of GABAergic transmission was higher in $\mathrm{NKCC1}^{-/-}$versus WT slices, indicating that the compensatory increase in network excitability takes place mainly within the glutamatergic population of neurons. Furthermore, there was a slight shift toward bigger mEPSCs in the $\mathrm{NKCC1}^{-/-}$slices, suggesting that the number or type of AMPA receptors or even the release probability of glutamatergic synapses might undergo a minor change in the $\mathrm{NKCC} 1^{-1-}$ mice. However, because the mean amplitude and frequency of mEPSCs were not significantly different in $\mathrm{NKCC1}^{-/-}$versus WT CA3 pyramidal neurons, a change in the properties of AMPA transmission is not likely to play a dominant role in the compensatory increase in network excitability. In contrast to this, a dramatic (sixfold) increase in the spiking frequency of immature $\mathrm{NKCC1}^{-/-}$versus WT CA3 pyramidal neurons was observed in the absence of GABAergic and glutamatergic transmission, which suggests that an increase in intrinsic neuronal 
A

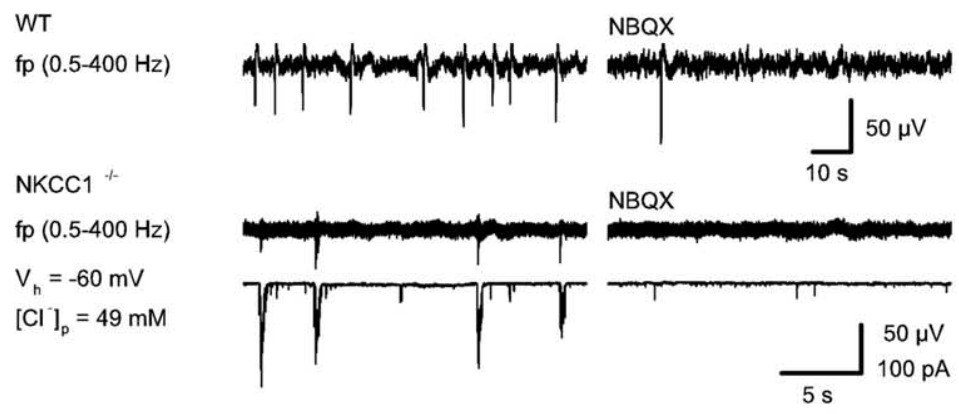

B

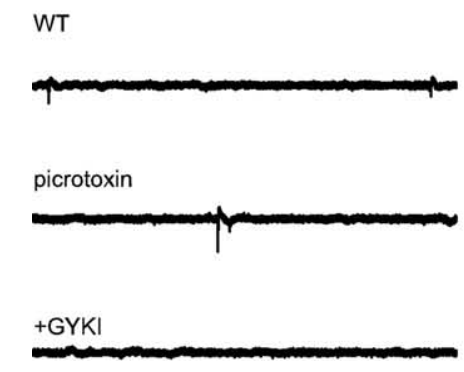

$\mathrm{NKCC}^{\%}$
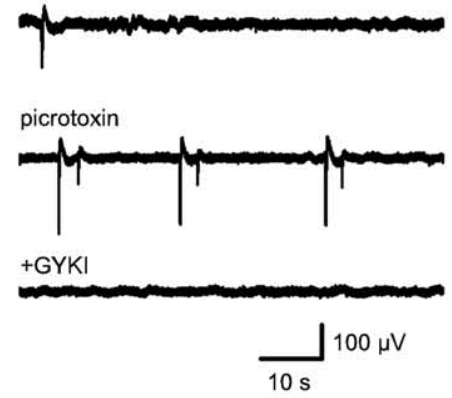

C
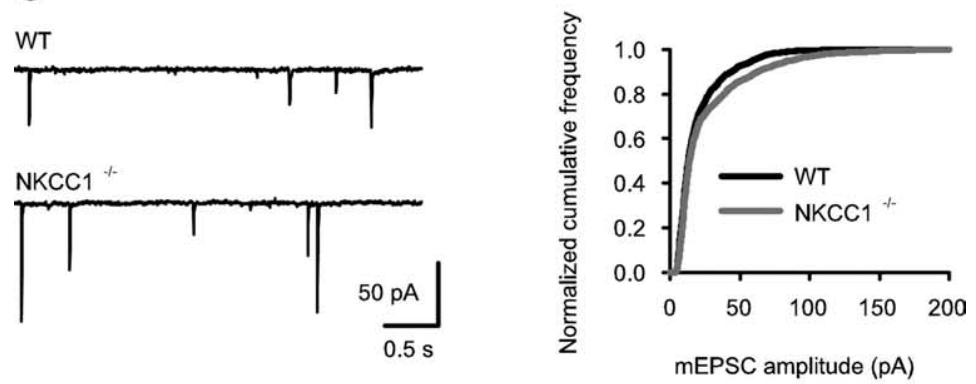

D

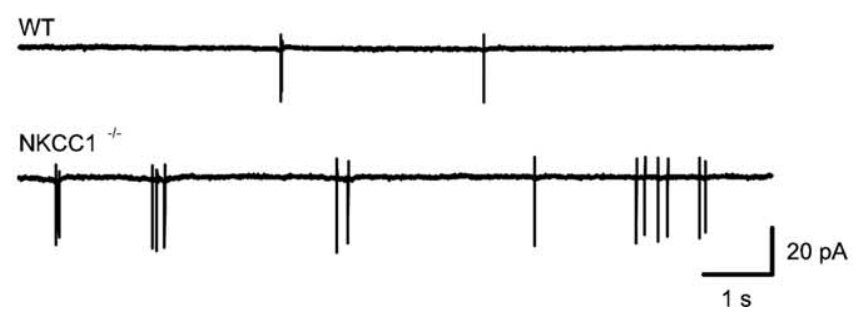

Figure 4. Enhanced AMPA receptor-mediated network events and intrinsic firing in neonatal $N K C C 1^{-1-}$ CA3 pyramidal neurons in the absence of $\mathrm{GABA}_{\mathrm{A}}$ signaling. $\boldsymbol{A}$, Top traces, The effect of the AMPA/kainate antagonist NBQX (50 $\left.\mu \mathrm{m}\right)$ on $\mathrm{fGDPs}$ in a WT slice. Bottom traces, Simultaneous fp and voltage-clamp $\left(V_{\mathrm{h}}\right.$ of $\left.-60 \mathrm{mV} ;\left[\mathrm{Cl}^{-}\right]_{\mathrm{p}}=49 \mathrm{~mm}\right)$ recordings from an $\mathrm{NKCC}^{-/-}$

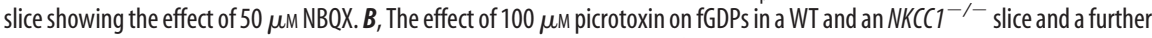
addition of $20 \mu \mathrm{M}$ GYKI53655. C, Left, mEPSCs recorded in WT and $N K C{ }^{-1-}$ CA3 pyramidal neurons. Right, Normalized cumulative peak mEPSC amplitude histograms obtained from 25 WT and $20 \mathrm{NKCC}^{-1-}$ CA3 pyramidal neurons. D, Cell-attached recordings from WT and $\mathrm{NKCC}^{-/-}$CA3 pyramidal neurons in the presence of NBQX, AP-5, and picrotoxin.

slow $\mathrm{Ca}^{+}$-activated $\mathrm{K}^{+}$current, $I_{\mathrm{h}}$, and Kv7/M channels (Bender et al., 2005; Sipilä et al., 2006a; Safiulina et al., 2008). Additional work is needed to identify the detailed mechanisms that account for the increase in the spiking propensity of the $\mathrm{NKCC1}^{-/-}$neurons.

The glutamatergic synapses in the immature hippocampus are thought to be born without functional AMPA receptors (Isaac et al., 1995; Durand et al., 1996) (but see Groc et al., 2006). During the developmental time window when GABA exerts its depolarizing action, the simultaneous activation of $\mathrm{GABA}_{\mathrm{A}}$ and NMDA receptors has been suggested to provide a key mechanism for the induction of functional AMPA signaling (BenAri et al., 1997; Wang and Kriegstein, 2008) (see also Ge et al., 2006). Strikingly, our results indicate that the absence of the pronounced NKCC1mediated GABAergic depolarization does not suppress the perinatal maturation of functional AMPA transmission in native CA3 pyramidal neurons. A possible explanation is that the observed increase in neuronal excitability is associated with a postsynaptic depolarization that removes the $\mathrm{Mg}^{2+}$ block of NMDA receptors, thereby unsilencing AMPA synapses.

The stereotypical bursts of GABAergic currents are a hallmark of GDPs (Fig. 2A) (Ben-Ari et al., 1989; Sipilä et al., 2006b). The finding that neonatal $\mathrm{NKCC1}^{-/-}$ slices generate GABAergic bursts that are similar to those seen in the wild-type mouse (Fig. $2 A$ ) supports the view that the interneuronal network events are a consequence, and not a cause, of GDPs (Bolea et al., 1999; Sipilä et al., 2005).

In conclusion, we demonstrate that depolarizing $\mathrm{GABA}_{\mathrm{A}}$ signaling is not an absolute requirement for (1) the upregulation of KCC2 that renders GABA hyperpolarizing, (2) the development of functional AMPA-type synapses, or (3) the generation of early spontaneous network activity in the developing hippocampus. More generally, our results support the view that the immature brain is able to functionally cope with major genetic disturbances, maintaining its endogenous activity by homeostatic regulation of neuronal signaling.

excitability compensates for the loss of depolarizing GABA actions (cf. Sipilä et al., 2005) in a homeostatic manner (Turrigiano and Nelson, 2004). A similar compensatory upregulation of intrinsic neuronal excitability was seen within a few hours after pharmacological block of NKCC1 in WT slices. The intrinsic properties of the neonatal CA3 pyramidal neurons are shaped by a number of factors, including the persistent $\mathrm{Na}^{+}$current, the
A closely related study on NKCC1 KO mice [based on another strain (Pace et al., 2000)] was published by Pfeffer et al. (2009) while the present paper was under review. In contrast to their results, we did not detect any reduction in the strength of AMPA synapses. Furthermore, our results indicate that the frequency of GDPs is not reduced simply by a loss of GABA-mediated excitation in the KO slices. Rather, the fact that $\mathrm{KO}$ slices can generate 
GDPs is most likely based on homeostatic upregulation of intrinsic neuronal excitability as a response to the lack of NKCC1based GABAergic excitation.

\section{References}

Achilles K, Okabe A, Ikeda M, Shimizu-Okabe C, Yamada J, Fukuda A, Luhmann HJ, Kilb W (2007) Kinetic properties of Cl uptake mediated by $\mathrm{Na}^{+}$-dependent $\mathrm{K}^{+}-2 \mathrm{Cl}$ cotransport in immature rat neocortical neurons. J Neurosci 27:8616-8627.

Ben-Ari Y, Cherubini E, Corradetti R, Gaiarsa JL (1989) Giant synaptic potentials in immature rat CA3 hippocampal neurones. J Physiol 416:303-325.

Ben-Ari Y, Khazipov R, Leinekugel X, Caillard O, Gaiarsa JL (1997) GABAA, NMDA and AMPA receptors: a developmentally regulated "menage a trois." Trends Neurosci 20:523-529.

Ben-Ari Y, Gaiarsa JL, Tyzio R, Khazipov R (2007) GABA: a pioneer transmitter that excites immature neurons and generates primitive oscillations. Physiol Rev 87:1215-1284.

Bender RA, Galindo R, Mameli M, Gonzalez-Vega R, Valenzuela CF, Baram TZ (2005) Synchronized network activity in developing rat hippocampus involves regional hyperpolarization-activated cyclic nucleotide-gated (HCN) channel function. Eur J Neurosci 22:2669-2674.

Blaesse P, Guillemin I, Schindler J, Schweizer M, Delpire E, Khiroug L, Friauf E, Nothwang HG (2006) Oligomerization of KCC2 correlates with development of inhibitory neurotransmission. J Neurosci 26:10407-10419.

Blaesse P, Airaksinen MS, Rivera C, Kaila K (2009) Cation-chloride cotransporters and neuronal function. Neuron 61:820-838.

Bolea S, Avignone E, Berretta N, Sanchez-Andres JV, Cherubini E (1999) Glutamate controls the induction of GABA-mediated giant depolarizing potentials through AMPA receptors in neonatal rat hippocampal slices. J Neurophysiol 81:2095-2102.

Chub N, O'Donovan MJ (1998) Blockade and recovery of spontaneous rhythmic activity after application of neurotransmitter antagonists to spinal networks of the chick embryo. J Neurosci 18:294-306.

Durand GM, Kovalchuk Y, Konnerth A (1996) Long-term potentiation and functional synapse induction in developing hippocampus. Nature 381:71-75.

Dzhala VI, Talos DM, Sdrulla DA, Brumback AC, Mathews GC, Benke TA, Delpire E, Jensen FE, Staley KJ (2005) NKCC1 transporter facilitates seizures in the developing brain. Nat Med 11:1205-1213.

Flagella M, Clarke LL, Miller ML, Erway LC, Giannella RA, Andringa A, Gawenis LR, Kramer J, Duffy JJ, Doetschman T, Lorenz JN, Yamoah EN, Cardell EL, Shull GE (1999) Mice lacking the basolateral Na-K-2Cl cotransporter have impaired epithelial chloride secretion and are profoundly deaf. J Biol Chem 274:26946-26955.

Ganguly K, Schinder AF, Wong ST, Poo M (2001) GABA itself promotes the developmental switch of neuronal GABAergic responses from excitation to inhibition. Cell 105:521-532.

Ge S, Goh EL, Sailor KA, Kitabatake Y, Ming GL, Song H (2006) GABA regulates synaptic integration of newly generated neurons in the adult brain. Nature 439:589-593.

Groc L, Gustafsson B, Hanse E (2006) AMPA signalling in nascent glutamatergic synapses: there and not there! Trends Neurosci 29:132-139.

Isaac JT, Nicoll RA, Malenka RC (1995) Evidence for silent synapses: implications for the expression of LTP. Neuron 15:427-434.

Jean-Xavier C, Mentis GZ, O’Donovan MJ, Cattaert D, Vinay L (2007) Dual personality of GABA/glycine-mediated depolarizations in immature spinal cord. Proc Natl Acad Sci U S A 104:11477-11482.
Khalilov I, Dzhala V, Ben-Ari Y, Khazipov R (1999) Dual role of GABA in the neonatal rat hippocampus. Dev Neurosci 21:310-319.

Khirug S, Huttu K, Ludwig A, Smirnov S, Voipio J, Rivera C, Kaila K, Khiroug L (2005) Distinct properties of functional KCC2 expression in immature mouse hippocampal neurons in culture and in acute slices. Eur J Neurosci 21:899-904.

Lamsa K, Palva JM, Ruusuvuori E, Kaila K, Taira T (2000) Synaptic GABA(A) activation inhibits AMPA-kainate receptor-mediated bursting in the newborn (P0-P2) rat hippocampus. J Neurophysiol 83:359-366.

Ludwig A, Li H, Saarma M, Kaila K, Rivera C (2003) Developmental upregulation of KCC2 in the absence of GABAergic and glutamatergic transmission. Eur J Neurosci 18:3199-3206.

Pace AJ, Lee E, Athirakul K, Coffman TM, O’Brien DA, Koller BH (2000) Failure of spermatogenesis in mouse lines deficient in the $\mathrm{Na}^{+}-\mathrm{K}^{+}-2 \mathrm{Cl}^{-}$ cotransporter. J Clin Invest 105:441-450.

Payne JA (1997) Functional characterization of the neuronal-specific K-Cl cotransporter: implications for $[\mathrm{K}+] \mathrm{o}$ regulation. Am J Physiol 273:C1516-C1525.

Pfeffer CK, Stein V, Keating DJ, Maier H, Rinke I, Rudhard Y, Hentschke M, Rune GM, Jentsch TJ, Hübner CA (2009) NKCC1-dependent GABAergic excitation drives synaptic network maturation during early hippocampal development. J Neurosci 29:3419-3430.

Rivera C, Voipio J, Payne JA, Ruusuvuori E, Lahtinen H, Lamsa K, Pirvola U, Saarma M, Kaila K (1999) The $\mathrm{K}^{+} / \mathrm{Cl}^{-}$co-transporter KCC2 renders GABA hyperpolarizing during neuronal maturation. Nature 397:251-255.

Safiulina VF, Zacchi P, Taglialatela M, Yaari Y, Cherubini E (2008) Low expression of Kv7/M channels facilitates intrinsic and network bursting in the developing rat hippocampus. J Physiol 586:5437-5453.

Sipilä ST, Huttu K, Soltesz I, Voipio J, Kaila K (2005) Depolarizing GABA acts on intrinsically bursting pyramidal neurons to drive giant depolarizing potentials in the immature hippocampus. J Neurosci 25:5280-5289.

Sipilä ST, Huttu K, Voipio J, Kaila K (2006a) Intrinsic bursting of immature CA3 pyramidal neurons and consequent giant depolarizing potentials are driven by a persistent $\mathrm{Na}$ current and terminated by a slow Ca-activated $\mathrm{K}$ current. Eur J Neurosci 23:2330-2338.

Sipilä ST, Schuchmann S, Voipio J, Yamada J, Kaila K (2006b) The cationchloride cotransporter NKCC1 promotes sharp waves in the neonatal rat hippocampus. J Physiol 573:765-773.

Titz S, Hans M, Kelsch W, Lewen A, Swandulla D, Misgeld U (2003) Hyperpolarizing inhibition develops without trophic support by GABA in cultured rat midbrain neurons. J Physiol 550:719-730.

Turrigiano GG, Nelson SB (2004) Homeostatic plasticity in the developing nervous system. Nat Rev Neurosci 5:97-107.

Tyzio R, Cossart R, Khalilov I, Minlebaev M, Hübner CA, Represa A, Ben-Ari Y, Khazipov R (2006) Maternal oxytocin triggers a transient inhibitory switch in GABA signaling in the fetal brain during delivery. Science 314:1788-1792.

Wang DD, Kriegstein AR (2008) GABA regulates excitatory synapse formation in the neocortex via NMDA receptor activation. J Neurosci 28:5547-5558.

Wang DD, Kriegstein AR (2009) Defining the role of GABA in cortical development. J Physiol 587:1873-1879.

Wojcik SM, Katsurabayashi S, Guillemin I, Friauf E, Rosenmund C, Brose N, Rhee JS (2006) A shared vesicular carrier allows synaptic corelease of GABA and glycine. Neuron 50:575-587.

Yamada J, Okabe A, Toyoda H, Kilb W, Luhmann HJ, Fukuda A (2004) $\mathrm{Cl}^{-}$ uptake promoting depolarizing GABA actions in immature rat neocortical neurones is mediated by NKCC1. J Physiol 557:829-841. 